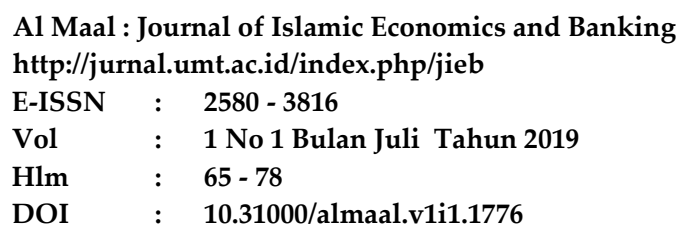

\title{
Strategi Penyelamatan Pembiayaan Bermasalah Pada Pembiayaan Murabahah Bank BNI Syariah Cabang Bogor
}

\author{
Ari Zulfikri ${ }^{1, *}$, Ahmad Sobari ${ }^{2}$, Syarifah Gustiawati ${ }^{3}$ \\ ${ }^{1,2,3}$ Prodi Ekonomi Syariah, Universitas Ibn Khaldun, Bogor, Indonesia \\ *Email : arizulfikri8@gmail.com
}

\begin{abstract}
In Islamic banking institutions, the term problem financing is not something foreign is heard. Almost all conventional and sharia banking institutions experience this, because not a few banking institutions are hampered by their growth and even have to stop their operations because they cannot overcome this problem. The Islamic banking sector is led to have a strategy in dealing with problem financing. Referring to the Bogor Branch of NPF Bank BNI Syariah data in 2016 (3.42\%), 2017 (2.78\%), 2018 (1.58), it is known that the NPF value at the Bogor Branch of BNI Syariah has decreased (considered good), because it is still below the maximum standard NPF value set by Bank Indonesia (5\%). Financing at the Bank BNI Syariah Bogor Branch continues to increase every year and the financing that is dominated is Murabahah financing. To achieve a good NPF value, the Bank BNI Syariah Bogor Branch uses a strategy to overcome problem financing, namely stay strategy and exit strategy. However, for the stage of saving the problematic financing the strategy used is to stay a strategy through financing restructuring efforts.
\end{abstract}

Keywords: Murabahah; Rescue; Problematic Financing; Restructuring; Strategy,

\begin{abstract}
ABSTRAK
Dalam lembaga perbankan syariah, istilah pembiayaan bermasalah bukan sesuatu hal yang asing didengar. Hampir semua lembaga perbankan baik kovensional maupun syariah mengalami hal tersebut, karena tidak sedikit lembaga perbankan yang terhambat laju pertumbuhannya bahkan harus terhenti kegiatan operasionalnya karena tidak bisa mengatasi masalah ini. Pihak perbankan syariah dituntun untuk memiliki strategi dalam menangani pembiayaan bermasalah. Merujuk pada data NPF Bank BNI Syariah Cabang Bogor pada tahun 2016 (3,42\%), 2017 (2,78\%), 2018 (1,58), diketahui bahwa nilai NPF di Bank BNI Syariah Cabang Bogor mengalami penurunan (dinilai baik), karena masih dibawah standar maksimal nilai NPF yang ditetapkan oleh Bank Indonesia (5\%). Pembiayaan di Bank BNI Syariah Cabang Bogor terus meningkat setiap tahunnya dan pembiayaan yang medominasi adalah pembiayaan Murabahah. Untuk mencapai nilai NPF yang baik, Bank BNI Syariah Cabang Bogor menggunakan strategi dalam mengatasi pembiayaan bermasalah yaitu stay strategi dan exit strategi. Namun untuk tahap penyelamatan pembiayaan bermasalah strategi yang digunakan adalah stay strategi melalui upaya restrukturisasi pembiayaan.
\end{abstract}

Kata kunci : Murabahah; Penyelamatan; Pembiayaan Bermasalah; Restrukturisasi; Strategi, 


\section{Pendahuluan}

Selama lima tahun terakhir perkembangan keuangan syariah di Indonesia sebagaimana disebutkan oleh OJK bahwa perkembangannya tercatat semakin baik. Di tahun 2017 industri keuangan syariah di Indonesia tumbuh sebesar 26,97 persen. Market share industri keuangan syariah Indonesia pada Desember 2017 mencapai 8,24 persen dari total aset keuangan di Indonesia. Adapun aset perbankan syariah di Indonesia pada tahun 2017 meningkat sebesar 0,45 persen. Sebelumnya, yaitu pada tahun 2016 market sharenya sebesar 5,34 persen dan tahun 2017 sebesar 5,78 persen. (Waluya \& Samsuri, 2018)

Bank syariah merupakan lembaga keuangan yang berfungsi sebagai perantara bagi pihak berlebihan dana dan pihak berkekurangan dana untuk kegiatan usaha dan kegiatan lainnya yang sesuai dengan hukum Islam. Jenis usaha bank syariah sebagai lembaga keuangan perantara (financial intermediary) secara simpel dapat dijalankan ke dalam pendanaan dan pembiayaan, serta jasa (Ismail, 2010:8). Pendanaan disebut juga dengan sisi liabilitas atau beban kewajiban yang harus dibayarkan oleh pihak bank kepada pihak nasabah penabung atau investor. Selanjutnya, pembiayaan disebut juga dengan aset, dikarenakan dana yang dipergunakan untuk pembiayaan merupakan aset (kekayaan) bank tersebut. Walaupun bisa jadi dana yang digunakan berasal dari dana pihak ketiga (DPK).

Pembiayaan atau financing merupakan istilah yang dipergunakan dalam bank syariah, sebagaimana istilah kredit atau lending dalam bank konvensional. Pembiayaan merupakan salah satu fungsi bank dalam menjalankan aktivitas penyaluran atau penggunaan dana (Muhamad, 2014). Dalam pelaksanaan pembiayaan, bank syariah harus memnuhi aspek syariah dan aspek ekonomi, yang berarti bahwa setiap realisasi pembiayaan kepada debitur, bank syariah harus tetap berpedoman kepada syariat Islam dan tetap mempertimbangkan perolehan keuntungan baik bagi pihak bank syariah maupun nasabah bank syariah.

Tingkat pendapatan atau perolehan keuntungan dari penyaluran pembiayaan merupakan tingkat pendapatan tertinggi bagi pihak bank syariah. Sejalan dengan hal tersebut, tingkat risiko yang ditimbulkan juga tinggi, tidak sedikit nasabah yang tidak mampu membayar kewajibannya dikarenakan kelalaian nasabah yang sengaja tidak membayar angsuran ataupun karena usahanya tidak berjalan dengan lancar. Oleh karena itu, penerapan manajemen risiko atas pembiayaan yang disalurkan sangat diperlukan. Karena, salah satu faktor utama yang dapat menentukan kesinambungan dan pertumbuhan dari sebuah lembaga adalah seberapa jauh lembaga tersebut dapat mengelola risiko yang muncul dari layanan yang diberikan.

Antara pihak bank syariah dengan nasabah debitur, sebelum melakukan transaksi pembiayaan selalu membuat kesepakatan yang disetujui oleh kedua pihak sebelumnya, dan kesepakatan tersebut tertulis dalam akad pembiayaan, baik untuk pembiayaan murabahah, mudarabah, dan musyarakah. Dengan demikian secara otomatis kedua pihak telah terikat oleh perjanjian dan hukum yang telah dibuat bersama(Harmeko, 2010:15). Akad yang dilakukan pada bank ada dua macam, yakni akad pembiayaan dan akad dengan notaris untuk mengikat jaminan yang diberikan nasabah kepada bank syariah.

Hal tersebut dilakukan oleh bank sebagai salah satu upaya preventif agar pihak bank syariah dapat terhindar dari pembiayaan bermasalah yang mungkin terjadi di kemudian hari. Namun demikian, upaya ini tidak dapat selalu menghindarkan pihak bank syariah dari risiko pembiayaan bermasalah yang mungkin terjadi di kemudian hari. 
Sejalan dengan permasalahan di atas, maka pihak bank syariah diharuskan untuk mempunyai upaya yang efektif dalam menangani pembiayaan bermasalah yang dimilikinya. Apabila didasarkan pada ketentuan yang dikeluarkan oleh Bank Indonesia, maka pihak bank harus menjaga jumlah pembiayaan bermasalah yang dimilikinya tidak lebih dari 5\%. Pada Desember 2018 rasio pembiayaan bermasalah di Bank Umum Syariah (BUS) tercatat sebesar 3,26\% menurun dari periode tahun sebelumnya 4,76\%. Perbaikan NPF tersebut berhasil dilakukan sejalan dengan strategi yang sudah dijalankan terbukti efektif dalam menangani pembiayaan bermasalah.

Secara umum, kasus pembiayaan bermasalah terjadinya tidak secara tiba-tiba, namun akan mengalami tahap bermasalah terlebih dahulu. pada tahap ini, pihak bank akan memberikan peringatan secara kekeluargaan, apabila nasabah tetap saja mengalami kesulitan untuk menyelesaikan kewajibannya, maka dengan persetujuan dari pihak nasabah dapat dilakukan upaya restrukturisasi pembiayaan.

Dijelaskan dalam Peraturan Bank Indonesia Nomor 13/9/PBI/2011 bahwa restrukturisasi pembiayaan adalah upaya yang dilakukan bank dalam rangka membantu nasabah agar dapat menyelesaikan kewajibannya, antara lain melalui: penjadwalan kembali (rescheduling), persyaratan kembali (reconditioning), dan penataan kembali (restructuring).

Adapun tujuan dari penelitian ini adalah untuk mengetahui strategi Bank BNI Syariah dalam menyelamatkan pembiayaan murabahah bermasalah pada Bank BNI Syariah Cabang Bogor.

\section{KAJIAN LITERATUR Pengertian Pembiayaan Bermasalah}

Yang dimaksud dengan pembiayaan, berdasarkan pasal 1 butir 25 UU No. 21 Tahun 2008 tentang Perbankan Syariah adalah penyediaan dana atau tagihan yang disamakan dengan itu berupa:

a) transaksi bagi hasil dalam bentuk Mudharabah dan musyarakah;

b) transaksi sewa-menyewa dalam bentuk Ijarah atau sewa beli dalam bentuk Ijarah Muntahiyah bit tamlik;

c) transakasi jual beli dalam bentuk piutang Murabahah, Salam, dan Istisna;

d) transaksi minjam meminjam dalam bentuk piutang mewajibkan pihak yang diardh; dan

e) transaksi sewa-menyewa jasa dalam bentuk ijarah untuk transaksi multijasa.

Berdasarkan persetujuan atau kesepakatan antara Bank Syariah dan/atau UUS dan pihak lain yang dibiayai dan/atau diberi fasilitas dana untuk mengembalikan dana tersebut setelah jangka waktu tertentu dengan imbalan ujrah, tanpa imbalan atau bagi hasil.

Berdasarkan pengertian diatas, maka setiap nasabah bank syariah yang mendapatkan pembiayaan dari bank syariah, wajib hukumnya untuk mengembalikan pembiayaan tersebut setelah jangka waktu tertentu, ditambah dengan bagi hasil atau imbalan atau tanpa imbalan untuk transaksi pembiayaan dalam bentuk qard.

Dalam Statistik perbankan syariah yang diterbitkan oleh Direktorat Perbankan Syariah Bank Indonesia dijelaskan bahwa istilah Non Performing Financing (NPF) untuk fasilitas pembiayaan di bank syariah maupun Non Performing Loan (NPL) untuk fasilitas kredit di bank konvensional diartikan sebagai pembiayaan non lancar mulai dari golongan kurang lancar sampai dengan macet (Djamil, 2012). 
Dari segi produktivitas dalam kaitannya dengan kemampuan untuk menghasilkan pendapatan bagi pihak bank, pembiayaan bermasalah akan mengalami penurunan atau sudah tidak lagi menghasilkan bagi pihak bank. Bahkan pembiayaan bermasalah sudah pasti akan mengurangi pendapatan bank, karena pembiayaan bermasalah yang semakin besar, akan menambah besar pula biaya pencadangan yang harus disisihkan atau dikenal dengan istilah PPAP (Penyisihan Penghapusan Aktiva Produktif)

Menurut Supramono (1996) Penyebab timbulnya suatu kredit atau pembiayaan bermasalah terdiri dari faktor internal dan eksternal perbankan. Faktor internal,yaitu penyebab pembiayaan bermasalah yang berasal dari bank itu sendiri, diantaranya:

a) Kualitas pejabat

b) Persaingan antar bank

c) Hubungan ke dalam. Hubungan ke dalam adalah hubungan bank dengan perusahaan lain yang tergabung dalam kelompoknya, serta hubungan bank dengan pengurus maupun dengan pemegang saham.

d) Pengawasan. Tindakan pengawasan dilakukan oleh pihak bank itu sendiri dan pihak Bank Indonesia.

Sedangkan faktor eksternal pembiayaan bermasalah disebabkan oleh nasabah pembiayaan, seperti nasabah side streaming yaitu nasabah menggunakan dana tidak sesuai dengan ketentuan akad, nasabah beritikad tidak baik, tidak jujur, lalai dan lain sebagainya. Dapat pula diidentifikasi penyebab timbulnya pembiayaan bermasalah anatara lain karena perubahan politik dan peraturan perundangan, diregulasi sektor rill, keuangan dan ekonomi.

Perubahan kondisi tersebut diatas merupakan tantangan yang dihadapi oleh pemilik dan pengelola perusahaan. Suatu kunci menuju pengelolaan sukses dari suatu usaha adalah kemampuan mengantisipasi perubahan dan cukup Fleksibel dalam mengelola usahanya. Pembiayaan bermasalah akan timbul, dikarenakan oleh faktor eksternal dikarenakan gagalnya pengelola dalam mengantisipasi dan menyesuaikan diri dengan perubahan kondisi perekonomian, perubahan peraturan, dan bencana alam (Supramono, 1996) .

\section{Penyelamatan Pembiayaan Bermasalah}

Menurut Muhammad (2005) Penanganan pembiayaan bermasalah merupakan bagian yang tidak dapat dihindari dalam proses penyaluran pembiayaan. Karena setiap realisasi pembiayaan yang dilakukan pasti memiliki potensi pembiayaan bermasalah. Sehingga, jika ditemukan gejala dini pembiayaan bermasalah, maka harus segera diambil langkah penanganan yang tepat sebelum masalah menjadi semakin besar.

Secara garis besar upaya untuk mengatasi pembiayaan bermasalah dapat dilakukan melalui upaya-upaya yang bersifat preventif dan represif/ kuratif. Upaya yang bersifat preventif (pencegahan) dilakukan oleh bank sejak permohonan pembiayaan diajukan nasabah, pelaksanaan analisa yang akurat terhadap data pembiayaan, pembuatan perjanjian pembiayaan yang benar, pengikatan agunan yang menjamin kepentingan bank sampai dengan pemantauan atau pengawasan terhadap pembiayaan yang diberikan. Sedangkan upaya yang bersifat represif/kuratif adalah upaya mengatasi pembiayaan bermasalah yang bersifat penyelamatan atau penyelesaian terhadap pembiayaan bermasalah (Djamil, 2012).

Penyelamatan pembiayaan bermasalah merupakan upaya dan langkah-langkah restrukturisasi yang dilakukan bank dengan mengikuti ketentuan yang berlaku agar pembiayaan non lancar (golongan kurang lancar, diragukan, dan macet) secara bertahap menjadi golongan lancar kembali (Djamil, 2012). 
Proses penanganan pembiayaan yang bermasalah dapat dilakukan sesuai dengan golongannya, yaitu (Muhammad, 2005):

a) Pembiayaan lancar dilakukan dengan cara:

1) Pemantauan usaha nasabah.

2) Pembinaan anggota dengan pelatihan-pelatihan

b) Pembiayaan potensial bermasalah, dilakukan dengan cara:

1) Pembinaan anggota.

2) Pemberitahuan dengan surat teguran.

3) Kunjungan lapangan atau silaturahmi oleh bagian pembiayaan kepada nasabah.

4) Upaya preventif dengan penanganan rescheduling, yaitu penjadwalan kembali jangka waktu angsuran serta memperkecil jumlah angsuran. Juga dapat dilakukan dengan reconditioning, yaitu memperkecil keuntungan atau bagi hasil.

b) Pembiayaan kurang lancar, dilakukan dengan cara:

1) Membuat surat teguran atau peringatan.

2) Kunjungan lapangan atau silaturahmi oleh bagian pembiayaan kepada nasabah dilakukan dengan lebih bersungguh-sungguh.

3) Upaya penyehatan dengan cara rescheduling, yaitu penjadwalan kembali jangka waktu angsuran serta memperkecil jumlah angsuran. Juga dapat dilakukan dengan reconditioning, yaitu memperkecil margin keuntungan atau bagi hasil.

c) Pembiayaan diragukan/macet, dilakukan dengan cara:

1) Rescheduling, yaitu penjadwalan kembali jangka waktu angsuran serta memperkecil jumlah angsuran.

2) Reconditioning, yaitu memperkecil margin atau bagi hasil usaha.

3) Pengalihan atau pembiayaan ulang dalam bentuk pembiayaan qardalhasan.

Adapun Menurut Muhammad (2012) selain ketentuan-ketentuan di atas, terdapat beberapa ketentuan lain yang menjelaskan mengenai langkah-langkah restrukturisasi pembiayaan atau penanganan pembiayaan bermasalah berdasarkan prinsip syariah yang termasuk dalam berbagai peraturan perundang-undangan, yakni sebagai berikut:

a) Penurunan imbalan atau bagi hasil

b) Pengurangan tunggakan imbalan atau bagi hasil

c) Pengurangan tunggakan pokok pembiayaan

d) Perpanjangan jangka waktu pembiayaan

e) Penambahan fasilitas pembiayaan

f) Pengambilalihan aset debitur sesuai dengan ketentuan yang berlaku

g) Konversi pembiayaan menjadi penyertaan pada perusahaan debitur.

Langkah-langkah tersebut dalam pelaksanaannya bisa dilakukan secara bersamaan (kombinasi), misalnya pemberian keringanan jumlah kewajiban disertai dengan kelonggaran waktu pelunasan, perubahan syarat perjanjian dan sebagainya. Akan tetapi, kombinasi tidak diperlukan apabila upaya restrukturisasi dilakukan dengan konversi pinjaman menjadi penyertaan, maka pembiayaan debitur menjadi lunas.

Berkaitan dengan tata cara restrukturisasi pembiayaan, semua jenis pembiayaan dapat dilakukan restrukturisasi dengan tetap memperhatikan karakteristik dari masing- 
masing bentuk pembiayaan. Dalam Surat Edaran Bank Indonesia Nomor 10/34/DPbs tanggal 20 Oktober 2008 tentang Restrukturisasi Pembiayaan bagi Bank Umum Syariah dan Unit Usaha Syariah, dijelaskan mengenai restrukturisasi untuk masing-masing jenis pembiayaan. Pembiayaan dalam bentuk Piutang Murabahah dan piutang istisna' dapat dilakukan restrukturisasi dengan cara :

a) Penjadwalan Kembali (rescheduling)

Restrukturisasi dilakukan dengan memperpanjang jangka waktu jatuh tempo pembiayaan tanpa mengubah sisa kewajiban nasabah yang harus dibayarkan kepada Bank Umum Syariah atau Unit Usaha Syariah.

b) Persyaratan kembali (reconditioning)

Restrukturisasi dilakukan dengan menetapkan kembali syarat-syarat pembiayaan antara lain perubahan jadwal pembayaran, jumlah angsuran, jangka waktu dan/atau pemberian potongan sepanjang tidak menambah sisa kewajiban nasabah yang harus dibayarkan kepada Bank Umum Syariah atau Unit Usaha Syariah.

c) Penataan kembali (restructuring) dengan melakukan konversi piutang murabahah atau piutang istisna' sebesar sisa kewajiban nasabah menjadi ijarah muntahiyah bittamlik atau mudarabah atau musyarakah.

d) Penataan kembali (restructuring) dengan melakukan konversi menjadi Surat Berharga Syariah Berjangka Waktu Menengah.

e) Penataan kembali (restructuring) dengan melakukan konversi menjadi Penyediaan Modal Sementara.

Secara umum kualitas pembiayaan dapat dibagi menjadi lima golongan apabila didasarkan kepada penilaian prospek usaha, aspek kinerja (performance) nasabah, dan aspek kemampuan membayar atau kemampuan menyerahkan barang pesanan, yaitu golongan lancar, dalam perhatian khusus, kurang lancar, diragukan, dan golongan macet.

\section{Pembiayaan Murabahah}

Pembiayaan atau financing adalah pendanaan yang diberikan oleh suatu pihak kepada pihak lain untuk mendukung investasi yang telah direncanakan, baik dilakukan sendiri maupun lembaga. Dengan kata lain, pembiayaan adalah pendanaan yang dikeluarkan untuk mendukung investasi yang telah direncanakan (Siskawati, Hendri, Syarifah, 2015:17-18). Menurut Undang-Undang No. 21 tahun 2008 tentang perbankan syariah yang dimaksud dengan pembiayaan adalah penyediaan dana atau tagihan yang dipersamakan dengan itu berupa transaksi bagi hasil dalam bentuk mudharabah dan musyarakah, transaksi sewa menyewa dalam bentuk ijarah atau sewa beli dalam bentuk ijarah muntahiya bittamlik, transaksi jual beli dalam bentuk piutang murabahah, salam dan istishna, transaksi pinjam meminjam dalam bentuk piutang qardh, dan transaksi sewa menyewa jasa dalam bentuk ijarah untuk transaksi multi jasa.

Murabahah didefinisikan oleh para Fuqoha sebagai penjualan barang seharga biaya/ harga pokok (cost) barang tersebut ditambah mark-up atau margin keuntungan yang disepakati (Wiroso, 2005). Murabahah dapat dilakukan berdasarkan pesanan atau tanpa pesanan. Bank hanya melakukan transaksi murabahah dengan pesanan. Dalam murabahah berdasarkan pesanan, bank melakukan pembelian barang setelah ada pemesanan dari nasabah. Sementara dalam perspektif Undang-undang No. 21 tahun 2008 tentang Perbankan Syariah, murabahah merupakan produk finansial yang berbasis bai' atau jual beli. Pengertian Murabahah ini diatur dalam Undang-undang No. 21 Tahun 2008 tentang Perbankan Syariah pasal 19 ayat (1) huruf d, dijelaskan bahwa murabahah adalah 
"akad pembiayaan suatu barang dengan menegaskan harga belinya kepada pembeli dan pembeli membayarnya dengan lebih sebagai keuntungan yang dosepakati".

Menurut fatwa DSN-MUI, Pembiayaan Murabahah adalah fasilitas bank syariah bagi yang memerlukannya, yaitu menjual suatu barang dengan menegaskan harga belinya kepada pembeli dan pembeli membayarnya dengan harga yang lebih sebagai laba. Harga jual bank adalah harga beli pemasok ditambah keuntungan yang disepakati bersama (Kamil dan Fauzan, 2006).

Dari beberapa pengertian murabahah diatas secara kongkrit bisa digambarkan bahwa ada tiga pihak yang terlibat dalam murabahah, yaitu A,B dan C. A meminta B untuk membelikannya beberapa barang (komoditas). B tidak memiliki barang-barang yang dibutuhkan A tetapi B berjanji untuk mengembalikannya dari pihak ketiga, yaitu $\mathrm{C}$. Praktik Pembiayaan Murabahah pada Bank Syariah

Praktik pembiayaan murabahah yang diaplikasikan pada bank syariah, diawali dengan proses pengajuan pembiayaan oleh nasabah. Apabila telah disetujui maka berlanjut pada proses pencairan. Pada praktik penyaluran pembiayaan murabahah, bank bertindak sebagai pihak penyedia dana, baik sebagian atau seluruh dana yang dibutuhkan untuk membeli barang yang sesuai dengan kualifikasi nasabah. Selanjutnya, pembayaran oleh pihak nasabah dapat dilakukan secara tangguh sesuai dengan kesepakatan kedua pihak.

Pengajuan pembiayaan dalam bentuk barang oleh nasabah. Dalam tahap ini pihak bank dan nasabah akan melakukan negosiasi mengenai tiga aspek.

Aspek pertama mengenai teknis dan spesifikasi barang atau objek yang dibutuhkan oleh nasabah. Aspek kedua mengenai nominal harga barang yang dibutuhkan serta estimasi kemampuan nasabah untuk membayar secara tangguh. Kemudian aspek ketiga terkait jangka waktu pembiayaan. Penentuan jangka waktu pembiayaan disesuaikan pada kemampuan nasabah dalam membayar angsuran dari harga barang yang akan dibeli. Penentuan jangka waktu pembiayaan juga berpengaruh terhadap mark up price atau profit margin yang akan diambil oleh pihak bank.

Pada saat negosiasi dilakukan, maka akan terjalin kesepakatan antara kedua pihak, di mana pihak bank akan membeli barang yang dibutuhkan oleh nasabah sesuai dengan kualifikasi dalam negosiasi kepada supplier. Kemudian, pihak bank dan supplier bersama-sama mengirim barang tersebut kepada nasabah.

Setelah barang terkirim, maka nasabah harus segera melengkapi persyaratan yang tertuang dalam perjanjian formal, dalam tahapan ini maka asas formalisme telah terjadi. Nasabah diwajibkan untuk mengembalikan harga pokok barang yang dibeli ditambah dengan keuntungan yang telah disepakati pada saat negosiasi berlangsung. Jangka waktu pembiayaan berlangsung sebagaimana tertera dalam perjanjian dan akan berakhir sesuai dengan kesepakatan pada negosiasi. Ketika akad berakhir, maka kepemilikan barang akan menjadi milik nasabah sebagaimana pada transaksi jual beli (Dahlan, 2012).

\section{Metode Penelitian Pendekatan Penelitian}

Ditinjau dari jenis datanya pendekatan penelitian yang digunakan dalam penelitian ini adalah pendekatan kualitatif. Adapun menurut Meleong (2016) yang dimaksud dengan penelitian kualitatif yaitu penelitian yang bermaksud untuk memahami fenomena tentang apa yang dialami oleh subjek penelitian misalnya perilaku, persepsi, 
motivasi, tindakan, dll. secara holistik dan dengan cara deskripsi dalam bentuk kata - kata dan bahasa, pada suatu konteks khusus yang alamiah dan dengan memanfaatkan berbagai metode alamiah. Adapun jenis pendekatan penelitian ini adalah deskriptif. Penelitian deskriptif yaitu penelitian yang berusaha untuk menuturkan pemecahan masalah yang ada sekarang berdasarkan data-data. Jenis penelitian deskriptif kualitatif yang digunakan pada penelitian ini dimaksudkan untuk memperoleh informasi mengenai langkah-langkah yang dilakukan Bank BNI syariah dalam melakukan strategi penyelamatan pembiayaan bermasalah khusnya pada pembiayaan Murabahah.

\section{Tempat dan Waktu penelitian}

Penelitian tentang Strategi Penyelamatan Pembiayaan Bermasalah pada Pembiayaan Murabahah yang dilakukan di Bank BNI Syariah Cabang Bogor. Kegiatan penelitian ini dimulai sejak disahkannya surat ijin penelitian, yaitu bulan April sampai dengan Mei 2019.

\section{Objek dan Subjek Penelitian}

Objek dari penelitian ini adalah Langah-langkah yang dilakukan oleh Bank BNI Syariah dalam melakukan strategi penyelamatan pembiayaan bermasalah pada pembiayaan Murabahah. Bank BNI Syariah Cabang Bogor sebagai subjek penelitian.

\section{Jenis Data dan Sumber Data}

Data atau bahan keterangan ialah fakta yang dapat ditarik menjadi suatu kesimpulan dalam kerangka persoalan yang digarap (Tanjung dan Devi, 2013). Sedangkan menurut lofland sumber data utama dalam penelitian kualitatif ialah kata-kata dan tindakan, selebihnya adalah data tambahan seperti dokumen dan lain-lain. (Meleong, 2012). Dalam menyusun karya ilmiah ini, penulis menggunakan dua jenis sumber data yaitu :

\section{Sumber Data Primer}

Menurut Sandjaja dan Herimanto (2006) Sumber data primer meliputi karangan karangan asli yang ditulis oleh orang yang secara langsung mengalami, melihat atau mengerjakannya. atau data yang langsung memberikan data kepada pengumpul data, dalam hal ini adalah penulis. Data yang diperoleh penulis berupa data dari hasil wawancara dengan pihak yang terkait dengan Bank BNI Syariah Cabang Bogor serta dokumenter-dokumenter perusahaan, berupa arsip atau dokumen yang relevan dengan pembahasan penelitian penulis.

\section{Sumber Data Sekunder}

Sumber data sekunder adalah tulisan mengenai penelitian orang lain yang disajikan dalam bentuk komentar atau tinjauan pustaka oleh orang yang tidak secara langsung mengamati atau ikut serta terlibat (Tanjung dan Devi, 2012). Seperti bukubuku, majalah, internet, artikel, serta sumber-sumber lainnya yang mempunyai relevansi dengan penelitian ini.

\section{Teknik Pengumpulan Data}

Sesuai dengan permasalahan yang diangkat oleh peneliti, maka dalam pengumpulan data karya ilmiah ini peneliti menggunakan penelitian sebagai berikut pertama, penelitian Kepustakaan (library research), yaitu penelitian yang dilakukan dengan cara mengumpulkan dan mempelajari data-data dan bahan-bahan dari berbagai 
literatur dan daftar kesusastraan yang ada, seperti buku-buku, sumber dokumen perusahaan, majalah, surat kabar, via internet, dan kepustakaan lainnya yang mendung serta berkaitan dengan penelitian (Nuraida, 2010).

Kedua, penelitian lapangan (Field Research), adapun penelitian lapangan yang peneliti lakukan adalah dengan melakukan observasi ketempat penelitian dan wawancara dengan narasumber terkait. Wawancara adalah percakapan dengan maksud tertentu. Percakapan itu dilakukan oleh dua pihak, yaitu pewawancara (interviewer) yang mengajukan pertanyaan dan terwawancara (interviewee) yang memberikan jawaban atas pertanyaan itu (Meleong, 2012). Ada beberapa kelebihan pengumpulan data melalui wawancara, diantaranya metode terbaik untuk menilai keadaan pribadi, cocok sebagai kriterium (alat verifikasi) terhadap data hasil observasi, kuesioner, dll serta dapat dilakukan sambil observasi (Tanjung dan Devi, 2013). Wawancara dilakukan secara mendalam dan tidak terstruktur kepada subjek penelitian dengan pedoman yang telah dibuat. Teknik wawancara digunakan untuk mengungkapkan data tentang Strategi Penyelamatan Pembiayaan Bermasalah pada Pembiayaan Murabahah.

\section{Metode Analisis Data}

Penelitian ini adalah penelitian deskriptif, dengan lebih banyak bersifat uraian dari hasil wawancara dan studi dokumentasi. Data yang telah diperoleh akan dianalisis secara kualitatif serta diuraikan dalam bentuk deskriptif. Menurut Bogdan dan Biklen analisis data kualitatif adalah upaya yang dilakukan dengan jalan bekerja dengan data, mengorganisasikan data, memilah-milahnya menjadi satuan yang dapat dikelola, mensintesiskannya, mencari dan menemukan pola, menemukan apa yang penting dan apa yang dipelajari, dan memutuskan apa yang dapat diceritakan kepada orang lain (Meleong, 2012). Berdasarkan definisi tersebut maka analisis yang digunakan oleh peneliti adalah analisis induktif dengan menarik hal-hal yang bersifat khusus ke dalam hal-hal yang bersifat umum. Dalam logika induktif umumnya memerlukan penyajian bukti empirik yang cukup untuk membuat abstraksi (Muhadjir, 2000). Setelah dilakukan wawancara bagaimana strategi yang dilakukan oleh Bank BNI Syariah Cabang Bogor dalam penyelamatan pembiayaan bermasalah, kemudian ditafsirkan dengan kerangka pemikiran berdasarkan studi pustaka, terakhir adalah menarik kesimpulan sesuai dengan permasalahan penelitian.

\section{Hasil dan Pembahasan \\ Tahapan Proses Pembiayaan di Bank BNI Syariah Cabang Bogor}

Aplikasi pembiayaan murabahah di Bank BNI Syariah yaitu murabahah kepada pesanan pembelian, dengan penerapan pada produk pembiayaan untuk pembelian barangbarang investasi, baik domesti maupun luar negeri seperti melalui letter of credit (L/C).

Tahapan proses pembiayaan di Bank BNI Syariah Cabang Bogor menurut Sagileorus, (Wawancara, 2019) adalah sebagai berikut:

Pertama, nasabah pembiayaan murabahah datang ke Bank BNI Syariah untuk mengisi formulir aplikasi pembiayaan murabahah. Formulir aplikasi ini terdiri dari nama calon nasabah, jenis kelamin, nomor KTP, tanggal jatuh tempo KTP, alamat sesuai KTP, tempat tanggal lahir, pendidikan terakhir, status perkawinan, nama pasangan, nama ibu kandung, jumlah tanggungan, alamat dan nomor telepon tempat usaha dilengkapi dengan 
keterangan mengenai kegiatan usaha perusahaan, lama usaha, omset rata-rata per bulan, penawaran fasilitas cash pick up, serta tanda tangan calon nasabah.

Kedua, dokumen aplikasi yang telah diisi diserahkan kepada Sales Consumer (CS) untuk diverifikasi dan diperiksa kebenaran calon nasabah dalam mengisi formulir, serta kelengkapan dokumen aplikasi pembiayaan. Jika dokumen aplikasi pembiayaan calon nasabah belum lengkap, maka CS wajib meminta calon nasabah untuk segera melengkapi dokumen tersebut agar dapat dilanjutkan ke tahap selanjutnya.

Ketiga, dokumen aplikasi yang telah lengkap dan selesai diperiksa oleh CS, kemudian diserahkan kepada Unit Customer sales (UCS) untuk dilakukan penyelidikan informasi negatif calon nasabah melalui BI checking dan DHN-BI.

Keempat, setelah verifikasi dokumen aplikasi selesai, Direct Sales (DS) dan Sales Assisten, melakukan kunjungan ke tempat calon nasabah, mencari informasi mengenai karakter calon nasabah dan kebenaran tujuan pembiayaan yang akan diajukan.

Kelima, EFO Electronik Finencing orgination, melakukan verifikasi usaha calon nasabah yang terdiri dari lokasi usaha, jenis usaha, lamanya usaha, aktivitas usaha, persediaan barang, kebutuhan modal kerja dan informasi keuangan usaha.

Keenam, EFO melakukan analisa keuangan melalui proses scoring untuk menentukan Repayment Capacity (RPC) dan Innicial Disposible Income Ratio (IDIR). Proses ini bertujuan untuk memberikan informasi penting keputusan pembiayaan dan kemampuan calon nasabah dalam pembayaran angsuran.

Ketujuh, semua dokumen calon nasabah dan informasi mengenai usaha calon nasabah sudah lengkap, selanjutnya dikeluarkan persetujuan pembiayaan oleh pemegang Batas Wewenang Pemutus Persetujuan Pembiayaan (BWPP) yaitu UH, MMM, Pimpinan Cabang Pembantu dan Pimpinan Cabang.

Kedelapan, dana dicairkan dan diserahkan kepada calon nasabah melalui rekening tabungan Pembiayaan yang sebelumnya telah dibuat oleh calon nasabah pada saat pengajuan pembiayaan.

Setelah fasilitas pembiayaan disalurkan kepada nasabah, bagi Bank BNI Syariah tahap ini merupakan awal pemeliharaan dan pemantauan pembiayaan, yang disebut dengan tahap monitoring. Sebagaimana dijelaskan oleh Muhamad, bahwa dalam tahap pencairan, dana pembiayaan yang diterima oleh nasabah harus diarahkan untuk digunakan sebagaimana diajukan dalam permohonan yang telah disetujui oleh pihak bank, jangan sampai dana tersebut "bocor" dalam arti digunakan untuk kepentingan lain diluar kesepakatan. Selanjutnya, bank melakukan pembinaan dan kontrol atas aktivitas bisnis nasabah.

Secara teori, aspek teknis pembiayaan murabahah yakni bank harus menyediakan (aset murabahah) kebutuhan nasabah yang sesuai dengan kualifikasi yang telah disepakati pada saat negosiasi berlangsung, Namun dalam praktiknya, pihak Bank BNI Syariah Cabang Bogor hanya menyediakan dana pembiayaan dan pihak nasabah yang membeli barang kebutuhannya sendiri.

Hal ini terjadi karena jumlah nasabah yang cukup banyak, namun sumber daya insani yang tersedia terbatas, sehingga dengan mewakilkan kepada nasabah untuk memenuhi sendiri kebutuhannya dianggap lebih efektif dari pada pihak Bank harus memenuhi satu persatu kebutuhan nasabahnya. 
Namun demikian, hal tersebut belum dapat dikatakan sesuai dengan pedoman syariah yang ditetapkan oleh Majelis Ulama Indonesia, yakni fatwa Dewan Syariah Nasional Nomor 04/DSN-MUI/IV/2000 tentang murabahah. Karena sesuai dengan ketetapan yang ada, apabila pihak bank hendak mewakilkan kepada nasabah untuk membeli sendiri barang kebutuhannya, maka akad murabahah dilakukan setelah barang menjadi milik bank.

\section{Strategi Penyelamatan Pembiayaan Bermasalah Pada Pembiayaan Murabahah di Bank BNI Syariah Cabang Bogor.}

Menurut Tatang (Wawancara, 2019) pembiayaan bermasalah di Bank BNI Syariah adalah pembiayaan yang dalam pelaksanaan pembayaran bagi hasil atau margin, angsuran pokok pembiayaan, dan dalam penyampaian laporan belum mencapai atau memenuhi target yang diinginkan bank, dan memiliki kemungkinan risiko di kemudian hari seperti tidak tertagihnya pokok pembiayaan dan bagi hasil atau margin.

Salah satu indikasi bahwa fasilitas pembiayaan yang disalurkan akan bermasalah yakni apabila nasabah mengalami kesulitan dalam memenuhi kewajiban-kewajibannya kepada pihak bank, seperti nasabah terlambat melakukan pembayaran angsuran, hal semacam ini akan segera terbaca oleh sistem sehingga dapat dengan mudah untuk diketahui dan akan segera dilakukan upaya penagihan melalui telepon atau dengan kunjungan langsung ke tempat nasabah.

Pembiayaan bermasalah di Bank BNI Syariah adalah fasilitas pembiayaan dengan kolektibilitas lancar dan dalam perhatian khusus yang diperkirakan akan bermasalah, serta fasilitas pembiayaan dengan kolektibilitas kurang lancar, diragukan dan macet. Sehingga, tingkatan pembiayaan bermasalah di Bank BNI Syariah Cabang Bogor dapat digambarkan dalam tabel berikut ini:

Tabel 1 Tingkat Pembiayaan Bermasalah di Bank BNI syariah Cabang Bogor tahun 2019

\begin{tabular}{cc}
\hline Kol 1 & Nasabah telat mengangsur 0 hari \\
\hline Kol $2 a$ & Nasabah telat mengangsur 30 hari \\
Kol $2 b$ & Nasabah telat mengangsur 31-60 hari \\
Kol 2 c & Nasabah telat mengangsur 61-90 hari \\
Kol 4 & Nasabah telat mengangsur 181-270 hari \\
Kol 5 & Nasabah telat mengangsur $>270$ hari \\
Kol 6 & Hapus Buku \\
\hline
\end{tabular}

sumber : dokumen penagihan bank BNI Syariah

Penjelasan mengenai tabel di atas, berbeda dengan penjelasan Djamil (2012) bahwa pembiayaan yang masuk dalam kategori pembiayaan bermasalah atau pembiayaan non lancar merupakan pembiayaan dengan kolektibilitas kurang lancar, diragukan dan macet.

Namun, pihak Bank BNI Syariah Cabang Bogor menetapkan kolektibilitas lancar dan dalam perhatian khusus ke dalam pembiayaan bermasalah karena pihak bank telah memperkirakan bahwa pembiayaan tersebut memiliki potensi untuk bermasalah di 
kemudian hari. Hal ini dilakukan oleh Bank BNI Syariah Cabang Bogor sebagai upaya preventif untuk menghindari terjadinya pembiayaan bermasalah. Dengan demikian, maka pihak bank dapat melakukan pengawasan dan pemantauan secara intensif terhadap nasabah yang diketahui terlambat melakukan pembayaran.

Secara umum, penyebab timbulnya pembiayaan bermasalah di Bank BNI Syariah Cabang Bogor meliputi dua aspek, antara lain:

Pertama, aspek eksternal : aspek eksternal pembiayaan bermasalah adalah adanya perubahan ekonomi makro atau peraturan regulator.

Kedua, aspek internal: aspek internal penyebab timbulnya pembiayaan bermasalah dapat dibagi menjadi dua, yakni; aspek internal pihak nasabah dan aspek internal pihak bank. Penyebab pembiayaan bermasalah yang disebabkan dari aspek internal bank.

Menurut Tatang (Wawancara, 2019) beberapa hal yang sering menjadi penyebab pembiayaan bermasalah di Bank BNI Syariah Cabang Bogor:

a) Penurunan pendapatan usaha nasabah.

b) Cuaca alam yang tidak stabil sehingga tidak dapat diprediksi, dan berpengaruh terhadap hasil pertanian bagi nasabah petani.

c) Bank kejar target, sehingga analisa pembiayaan tidak terlaksana dengan sempurna.

d) Karyawan penagih yang kurang sopan ketika melaksanakan proses penagihan atau bertemu ke tempat nasabah, sehingga nasabah tidak tertarik untuk membayar.

e) Angsuran Nasabah tidak memiliki itikad baik untuk membayar.

Menurut Tatang, (Wawancara, 2019) bahwa penanganan pembiayaan bermasalah di dalam Bank BNI Syariah Cabang Bogor, bukanlah suatu hal yang bisa dianggap remeh, selain harus memperhatikan prinsip-prinsip di atas, dalam menangani pembiayaan bermasalah Bank BNI Syariah Cabang Bogor mempunyai dua strategi yang nantinya akan digunakan dalam proses penanganan pembiayaan bermasalah yang terjadi. Dua strategi yang digunakan dalam proses penanganan pembiayaan bermasalah adalah stay strategy dan exit strategy.)

Strategi pertama yang digunakan oleh Bank BNI Syariah Cabang Bogor yakni stay strategy atau dengan kata lain cooperative strategy, merupakan strategi di mana pihak bank masih ingin mempertahankan hubungan bisnis dengan nasabah dalam konteks waktu jangka panjang. Strategi ini dilaksanakan dengan menggunakan upaya-upaya restrukturisasi (seperti rescheduling, reconditioning, dan restructuring).

Strategi kedua yang digunakan adalah exit strategy atau dengan kata lain phase out strategy, merupakan strategi dimana pihak bank tidak ingin melanjutkan hubungan bisnis lagi dengan nasabah dalam konteks waktu jangka panjang kecuali ada faktor-faktor lain yang sangat mendukung kemungkinan adanya perbaikan kondisi nasabah.

Strategi ini dilaksanakan dengan menggunakan Remedial dan Recovery (seperti lelang eksekusi baik melalui pihak manajemen bank, pengadilan, maupun melalui Basyarnas). Kecuali kondisi nasabah masih memiliki kemungkinan untuk diperbaiki, maka dalam kondisi yang demikian dapat digunakan upaya pendekatan secara halus 
(seperti pendampingan manajemen, novasi, kompensasi, subrogasi, penyertaan, dan likuidasi di bawah tangan).

Namun dalam pembahasan ini, penulis hanya akan fokus menjelaskan mengenai stay strategy yang digunakan oleh Bank BNI Syariah Cabang Bogor, dikarenakan fokus penelitian ini merupakan penelitian mengenai strategi yang digunakan dalam menyelamatkan pembiayaan bermasalah yang terjadi kepada nasabah Bank BNI Syariah Cabang Bogor.

Salah satu strategi penyelamatan pembiayaan bermasalah yang digunakan adalah dengan upaya restrukturisasi, yakni upaya perbaikan yang dilakukan oleh Bank BNI Syariah Cabang Bogor dalam rangka membantu nasabah agar dapat menyelesaikan kewajibannya. Dimana tujuan dari restrukturisasi pembiayaan adalah penyelamatan pembiayaan sekaligus menyelamatkan usaha debitur agar sehat kembali.

\section{KESIMPULAN}

Penelitian ini bertujuan untuk mengetahui strategi penyelamatan pembiayaan bermasalah pada pembiayaan murabahah yang digunakan oleh Bank BNI Syariah Cabang Bogor. Pihak Bank BNI Syarah Cabang Bogor mampu menjaga menjaga angka NPF yang dimilikinya tidak melebihi ketentuan yang telah ditetapkan oleh Bank Indonesia. Hal ini membuktikan bahwa strategi yang digunakan efektif untuk dilakukan.

Berdasarkan hasil penelitian yang telah dijelaskan pada bab sebelumnya, maka dapat disimpulkan bahwa secara umum strategi penanganan pembiayaan bermasalah yang digunakan oleh Bank BNI Syariah Cabang Bogor ada dua, yakni stay strategy dan exit strategy.

Namun, dalam penyelamatan pembiayaan bermasalah, strategi yang digunakan oleh Bank BNI Syariah Cabang Bogor stay strategy, yakni strategi yang digunakan apabila pihak bank masih ingin menjalin hubungan bisbis dengan nasabah. Stategi ini dilaksanakan melalui upaya restrukturisasi (seperti rescheduling,reconditioning dan restructuring).

\section{REFERENSI}

Ahmad, Solihin. 2010. Strategi Penyelesaian Pembiayaan Bermasalah akad Murabahah pada PT Bank Syariah Mandiri Kantor Cabang Selat Panjang. Skripsi. Riau: UIN Riau.

Dahlan, Ahmad. 2012. Bank Syariah Teoritik, Praktik, Kritik. Yogyakarta: Teras.

Daryoko. 2015. Penyelesaian Pembiayaan Bermasalah Dalam pelaksanaan Akad Murabahah di BNI Syariah Cabang Yogyakarta. Skripsi. Yogyakarta: UIN Yogyakarta.

Data Bank BNI Syariah Cabang Bogor.

Djamil, Faturrahman. 2012. Penyelesaian Pembiayaan Bermasalah Di Bank Syariah. Jakarta: Sinar Grafika.

Dokumen Bank BNI Syariah. Laporan Tahunan Bank BNI Syariah Tahun 2017

Harnoko. 2010. Hukum Perjanjian Asas Proporsionalitas Dalam Kontrak Komersil. Jakarta: Kencana. 
Ismail. 2010. Manajeman Perbankan. Jakarta: Kencana.

Kamil. M. Fauzan. 2006. Kitab Undang-Undang Hukum Perbankan dan Ekonomi Syariah. Jakarta: Kencana.

Kasmir. 2002. Bank Dan Lembaga Keuangan Lainnya. Jakarta: Grafindo Persada.

Moleong, J, Lexy. 2012. Metodologi Penelitian Kualitatif Edisi Revisi, Bandung: PT Remaja Roesdakarya.

Muhadjir, Neong. 2000. Metodologi Penelitian Kualitatif Edisi IV Cet. I, Yogyakarta: Rake Sarasin.

Muhamad. 2005. Manajemen Pembiayaan Bank Syariah. Yogyakarta: UPP AMP YKPN.

Muhamad. 2014. Manajemen Dana Bank Syariah. Jakarta: Raja Grafindo Persada.

Nuraida, Ida. 2010. "Manajemen Pembiayaan Muḍarabah Bermasalah (Studi pada Bank Muamalat Indonesia, Tbk)". Skripsi. Jakarta: UIN Jakarta.

Prabowo, Bagya Agung. 2012. Aspek Hukum Pembiayaan Murabahah pada Perbankan Syariah. Yogyakarta: UII Press.

Sholihat, Tanjung, Gustiawati, Analisis Efektivitas Pembiyaan Lembaga Keuangan Mikro Syariah Terhadap Perkembangan Usaha Nasabah di Sektor Rill (Usaha Mikro, Kecil dan Menengah). Jurnal Ekonomi Syariah, Vol. 6 No. 1, 2015

Sumitro Warkum. 2002. Asas - Asas Perbankan Islam Dan Lembaga-Lembaga Terkait BMI \& Takaful Di Indonesia. Jakarta: Grafindo Persada.

Supramono, Gatot. 1996. Perbankan dan Masalah Kredit:Suatu Tinjauan Yuridis. Jakarta: Djambatan.

Tanjung, Hendri \& Abrista Devi. 2013. Metodologi Penelitian Ekonomi Islam. Jakarta: Gramata Publishing.

Wiroso. 2005. Jual Beli Murabahah. Yogyakarta: UII Press.

Waluya, Atep Hendang \& Samsuri. 2018. Hubungan Persepsi Masyarakat Kota Serang Tentang Hukum Syariah Menabung Di Bank Dengan Tingkat Literasi Keuangan Syariah. Al-Infaq: Jurnal Ekonomi Islam. Vol 1 No 9. Hlm. 1

Yudistira, Reza. 2011. "Strategi Penyelesaian Pembiayaan Bermasalah pada Bank Syariah Mandiri”. Skripsi. Jakarta: UIN Jakarta 